\title{
Quantification of the Land Potential for Scaling Agroforestry in South Asia
}

\author{
Firoz Ahmad ${ }^{1}$ (D ) Md. Meraj Uddin ${ }^{2} \cdot$ Laxmi Goparaju $^{1} \cdot$ Javed Rizvi $^{3} \cdot$ Chandrashekhar Biradar $^{4}$
}

Received: 12 December 2019 / Accepted: 21 April 2020 / Published online: 4 May 2020

(c) The Author(s) 2020

\begin{abstract}
Trees are an integral part of the sustainable farming practices that can withstand extreme weather events, pest risks, and optimize land and water productivity to achieve food, fuel, fodder and nutritional security while safeguarding the environmental flows. This study was undertaken to analyze the landscape potential for the South Asian region in the geospatial domain utilizing the FAO's land suitability criteria. The key datasets were derived from satellite remote sensing at a global and regional scale for land, soil, climate, and topography and were used to model the agroforestry suitability across South Asia. Furthermore, the agroforestry suitability categories and tree cover dominance were investigated with respect to the total geographical area, agriculture land cover and with climate variables to understand the present and future trends. The comprehensive analysis revealed that $69 \%$ of the total geographical area retains $55 \%$ and greater suitability for agroforestry. The analysis revealed that nearly $73.4 \%$ of the landscape is absent $(0 \%)$ of tree cover, $7.1 \%$, shows $1-10 \%$ and $19.5 \%$ area having more than $10 \%$ tree cover. The tree dominance/hotspot analyses in the agriculture land were found notably high in the multiple farming components such as home gardens. The single crop of irrigated and rain-fed croplands showed high land suitability towards agroforestry. Such land can be utilized to enhance the tree cover that suits locally as per the farmer's need based on a community-driven participatory approach to bring the sustainability and resilience in degraded landscapes (FAO in Agroforestry for landscape restoration, 2017). The future climate data analysis showed a significant change in the distribution of temperature and precipitation that will influence future farming practices in South Asia. The agroforestry suitability and tree cover mapping results/analysis will assist crucially the agroforestry policymakers/planners in the various South Asian countries to implement and extend it to the new area. The analysis clearly shows that the advent of big data, remote sensing and GIS provide insights into the agroforestry interventions and scaling which further helps in building resilient landscapes for sustainable agri-food systems, livelihoods, safeguarding the environmental security and supporting some of the important sustainable development goals (SDGs).
\end{abstract}

Keywords Agroforestry · GIS $\cdot$ Land evaluation $\cdot$ Tree cover $\cdot$ Climate change $\cdot$ South asia

\section{Zusammenfassung}

Bäume sind ein integraler Bestandteil nachhaltiger landwirtschaftlicher Praktiken, die extremen Wetterereignissen und Schädlingsrisiken standhalten und die Land- und Wasserproduktivität optimieren können, um Nahrungs-, Treibstoff-, Futter- und Ernährungssicherheit zu erreichen. Diese Studie wurde durchgeführt, um das Landschaftspotenzial für die Region Südasien zu analysieren, wobei die Kriterien der FAO zur Landnutzung verwendet wurden. Die Schlüsseldatensätze wurden aus der satellitengestützten Fernerkundung im globalen und regionalen Maßstab für Land, Boden, Klima und Topographie abgeleitet und zur Modellierung der agroforstlichen Eignung in ganz Südasien verwendet. Darüber hinaus wurden die agroforstlichen Eignungskategorien und die Dominanz der Baumdecke in Bezug auf die gesamte geographische Fläche, die

Electronic supplementary material The online version of this article (https://doi.org/10.1007/s42489-020-00045-0) contains supplementary material, which is available to authorized users.

Firoz Ahmad

adfiroz@yahoo.com

Extended author information available on the last page of the article 
landwirtschaftliche Bodenbedeckung und mit Klimavariablen untersucht, um die gegenwärtigen und zukünftigen Trends zu verstehen. Die Analyse ergab, dass 55\% der Agroforstwirtschaftsfläche für diese Nutzung erhalten bleiben sollte. Insgesamt kommen für die Agroforstwirtschaft 69\% des gesamten Untersuchungsgebietes in Frage. 73,4 \% der Landschaft ist ohne Baumbedeckung, 7,1 \% der Fläche haben eine geringe Baumbedeckung (bis $10 \%$ ) und 19,5\% der Fläche haben mehr als 10 \% Baumbedeckung. Partikuläre Hausgärten haben verhältnismäßig einen dichteren Baumbestand. Niederschlagsversorgte oder bewässerte Ackerflächen zeigen eine hohe Eignung für die Agroforstwirtschaft. Nach den Empfehlungen der FAO sollten diese Flächen für die Anpflanzung von Bäumen genutzt werden. Dies entspräche den Bedürfnissen der Bauern vor Ort und zwar auf der Grundlage eines gemeindegetragenen partizipatorischen Ansatzes, um Nachhaltigkeit und Widerstandsfähigkeit in degradierten Landschaften zu erreichen. Die Analyse der zukünftigen Klimadaten zeigt eine signifikante Veränderung in der Verteilung von Temperatur und Niederschlag, welche Einfluss auf die landwirtschaftliche Nutzung in Südasien haben wird. Die Ergebnisse dieser Studie zur Eignungsuntersuchung von geeigneten Agroforstflächen kann Entscheidungsträgern/ Planern für die Ausweisung neuer Gebiete zur Aufforstung helfen. Die Methoden der Fernerkundung, GIS und die Big Data Analyse tragen dazu bei, nachhaltige Agrar- und Lebensmittelsysteme aufzubauen, die Umweltsicherheit zu gewährleisten und einige der wichtigen Ziele der nachhaltigen Entwicklung zu unterstützen.

\section{Introduction}

The United Nations has set 17 Sustainable Development Goals (SDGs) to be achieved over the next one and a halfdecade for the betterment of society while maintaining the landscape potentiality. Agroforestry has immense potential to fulfill the social, economic and ecological goals of large population and simultaneously improves the land quality by enhancing the soil fertility (Nair 1984, 2011; Dollinger and Jose 2018), enhancing the ecosystem services (Kuyah et al. 2016) and mitigating climate change impact (Ospina 2017). The agroforestry directly or indirectly can contribute significantly to some of the most challenging goals such as SDG 1 for ending poverty, SDG 2 for mitigating hunger/ achieve food security/improved nutrition/promote sustainable agriculture, SDG 3 for healthy lives and promote wellbeing, SDG 5 for women and girls' empowerment, SDG 6 to SDG 7 for clean water and affordable clean energy, SDG 13 for mitigating the climate change and its impacts, SDG 15 for sustainable forestry and restoration of degraded land and lt biodiversity loss (Mbow et al. 2014; Waldron et al. 2017; Montagnini and Metzel 2017). Such goals can be achieved on the existing land-use systems with appropriate strategies by orienting higher levels of integration of financial and human resources, policy/institutional space within the existing frameworks and when modeled from national/global to local development planning (Noordwijk et al. 2018).

Land capital is finite which needs to be prudently tapped for the benefit of mankind and livestock in a sustainable manner in the increased population scenario as per scientific land evaluation criteria (FAO 1976). Agroforestry got adequate focus in the world due to the global effort in the research and development. They addressed the issues in an integrated approach of the most crucial land-management goals and highlighted that one billion of agriculture land retain more than $10 \%$ tree cover, still several categories of land use/land cover globally have the capacity and can be utilized under various agroforestry practices (Nair and Garrity 2012). International organizations are continuously doing intensive research on agroforestry to achieve livelihood blueprint for the poor people around the globe, as well as for the improvement in environmental services.

The present analysis revolves around the South Asian countries which are suffering from frequent crop failure, poverty and severe weather events (Kaur and Kaur 2017) Therefore. a synergic approach/policy in terms of agroforestry needs to be assessed and prioritized. The climate change prediction reflects that more climate variations can be observed in the future, for example, temperature increase (Lal et al. 1995) and persistent drought (Ramanathan et al. 2005) in the Asian region. The previous studies have shown less number of rainy days (Goswami et al. 2006), frequent floods (Shrestha 2008), more frequent and intense weather events related with El-Nino (Trenberth and Hoar 1997; Aldhous 2004) and severe heatwaves (Zhai and Pan 2003) in many countries of the Asian continent. Agroforestry retains permanent tree cover and varied ecological niches with temporal and spatial management options which have the capacity to tolerate climate variability (Thorlakson and Neufeldt 2012), to build resilience (Torquebiau 2016) and support significantly to the agriculture sector.

The systematic logical evaluation of land is required on the basis of suitability and should be expanded in new areas which will benefit the poverty-stricken people and farmers. The policymakers of South Asian countries who are working in agroforestry/forestry/agriculture/rural development need such data to understand and implement at various levels of project planning and management. 
low suitable for plant growth (Fischer et al. 2008). Class 5 is non-soil, class 6 is permanent frost and class 7 is water areas (Fischer et al. 2008). The current study utilized class 1 to class 4 for agroforestry suitability mapping whereas class 5 to class 7 were categorized not suitable due to difficulties/constraints.

The annual climate data (1970-2000) such as Temperature (BIO1) and Precipitation (BIO12) which were in 30 arc-second $(1 \mathrm{~km})$ spatial resolution were utilized in this study. These climate data were collected from different weather stations throughout the globe and interpolated using thin-plate splines technique (Fick and Hijmans 2017). We have used the mean annual aridity data (Trabucco and Zomer 2009) which was in 30 arc-second (1 km) spatial resolution derived from long-term climate data (Hijmans et al. 2005). The digital elevation model (GTOPO30) (https ://earthexplorer.usgs.gov/) retains the grid spacing of $1 \mathrm{~km}$ and has significant improvement with respect to consistent coverage, scale, quality, and vertical accuracy (Danielson and Gesch 2011).

The Moderate Resolution Imaging Spectroradiometer NDVI raster surface generated using the software USGS EROS MODIS Direct Broadcast System (DBS) with 7 days composite and has a 250-m spatial resolution (Jenkerson et al. 2010) was used in this study for deriving the NDVI map.

We have utilized the whole raster data of tree cover 2000 (Hansen et al. 2013) of South Asia depicted in a grid cell in the form of the percent $(0-100)$. The data have the spacing 1-arc seconds (30-m spatial resolution) created using Landsat images (trees are defined here as all vegetation taller than $5 \mathrm{~m}$ in height) and is a bonanza in the twenty-first century for environmental monitoring/changes to achieve sustainability (Hansen et al. 2013).
The VEGA 2000 land cover dataset covering the South Asian region was used in the present study which has a spatial resolution of one kilometer and utilizes the standard FAO Land Cover Classification System (LCCS) with regional expert knowledge to categorize the landcover classes (Tateishi et al. 2011). We have used the agriculture/cropland mask from VEGA 2000 land cover datasets and further examined the tree cover percent in this.

Irrigated Area Map Asia (2000) which retains categories such as Irrigated (single/double/triple) crops and rainfed crops were used to segregate our result further.

The predicted (2030) temperature and rainfall variability grid data in South Asia (NCAR GIS Program 2012) were utilized and raster maps were generated. Furthermore, the time series precipitation data (20 annual sets) were downloaded (https://www.climatologylab.org/terra climate.html). The present decadal (2006-2015) annual precipitation deficit area map was created by comparing it with 20 years back decadal annual precipitation data (1976-1985). In the present study, most of the data were evaluated at the vector grid spacing $10 \mathrm{~km} \times 10 \mathrm{~km}$. The mean raster values of each parameter (multiple spatial resolution data) were brought into in separate column in a polygon vector file which was later used for GIS modeling. We have investigated a few layers using GIS complex Query to understand the multidimensional relationship among them.

\subsubsection{Harmonized Soil Data Suitability Map for Plants}

The various harmonized soil data themes which are crucial for plant growth to regulate their metabolic activities (Nachtergaele et al. 2009; Moulatlet et al. 2017) were integrated into the GIS domain by assigning equal weight to

Table 1 Detail of the data used for analysis

\begin{tabular}{|c|c|}
\hline Data utilized & Data source \\
\hline Harmonized World Soil Database & $\begin{array}{l}\text { https://webarchive.iiasa.ac.at/Research/LUC/External-World-soil-database/HTML/ } \\
\text { SoilQualityData.html?sb=11 (Fischer et al. 2008) }\end{array}$ \\
\hline Climate data & https://worldclim.org/bioclim \\
\hline Digital elevation model & https://earthexplorer.usgs.gov/ \\
\hline MODIS NDVI data & https://earthexplorer.usgs.gov/ \\
\hline Mean annual aridity data & $\begin{array}{l}\text { https://cgiarcsi.community/data/global-aridity-and-pet-database/ } \\
\text { (Trabucco and Zomer 2009) }\end{array}$ \\
\hline Tree cover 2000 & $\begin{array}{l}\text { https://earthenginepartners.appspot.com/science-2013-global-forest/download_ } \\
\text { v1.0.html (Hansen et al. 2013) }\end{array}$ \\
\hline Harmonized land cover database of Asia & https://forobs.jrc.ec.europa.eu/products/glc2000/products.php (Tateishi et al. 2011) \\
\hline Irrigated Area Map Asia (2000) & https://waterdata.iwmi.org/applications/irri_area/ \\
\hline $\begin{array}{l}\text { Prediction (2030) of temperature and rainfall anomalies (cli- } \\
\text { mate change scenario) }\end{array}$ & https://gisclimatechange.ucar.edu/ (NCAR GIS Program 2012) \\
\hline The present decadal (2006-2015) precipitation deficit area & https://www.climatologylab.org/terraclimate.html \\
\hline
\end{tabular}


each theme described in Fig. 1. The harmonized soil data suitability for plant maps generated is given in Fig. 2.
Such soil data provide crop cultivation potential under given agro-climatic/terrain conditions providing the basis for land evaluation (FAO 1976).
Fig. 1 GIS Integration and modeling for generating harmonized soil data suitability for plants
Fig. 2 Harmonized soil data suitability map for trees
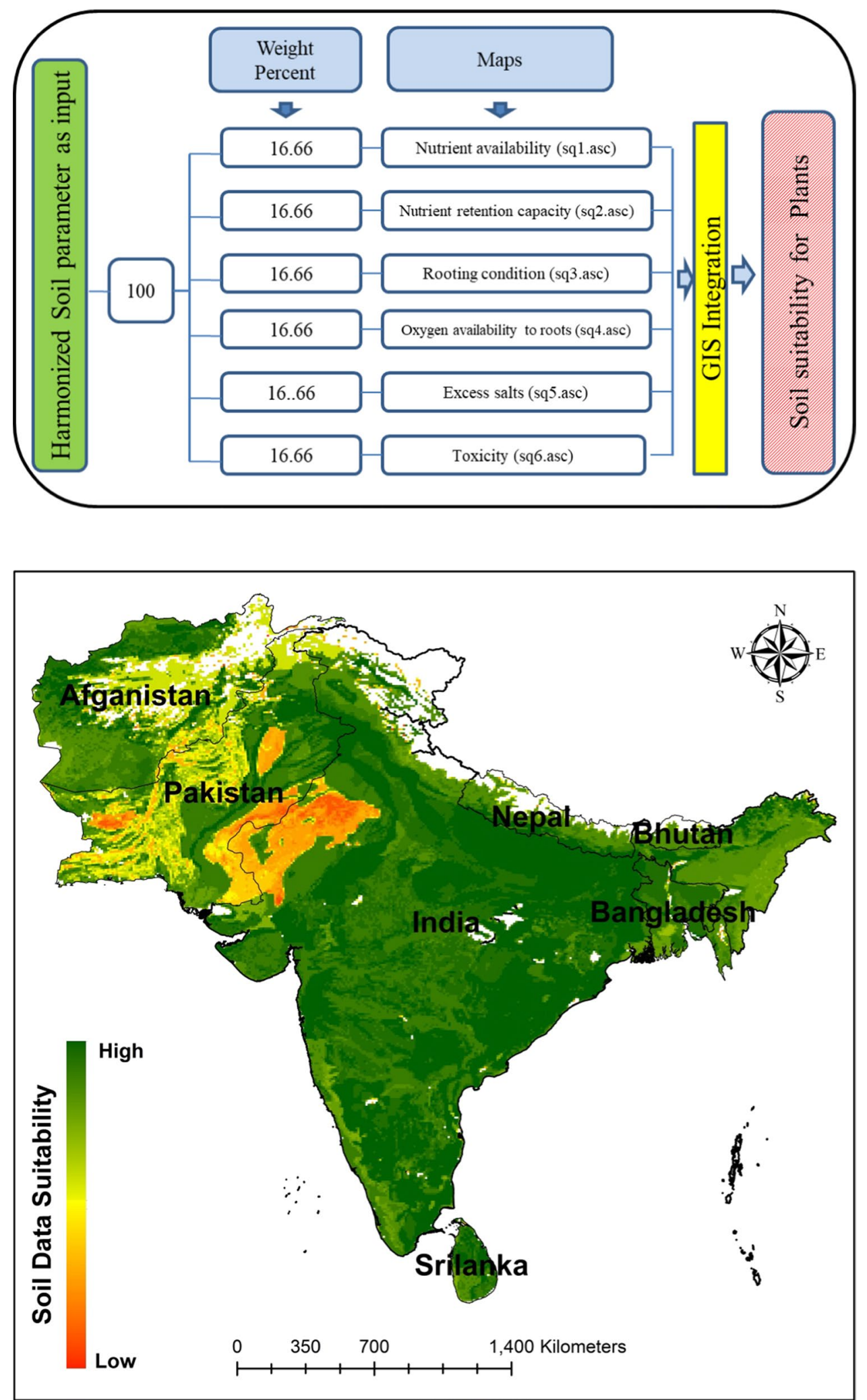
Fig. 3 NDVI map

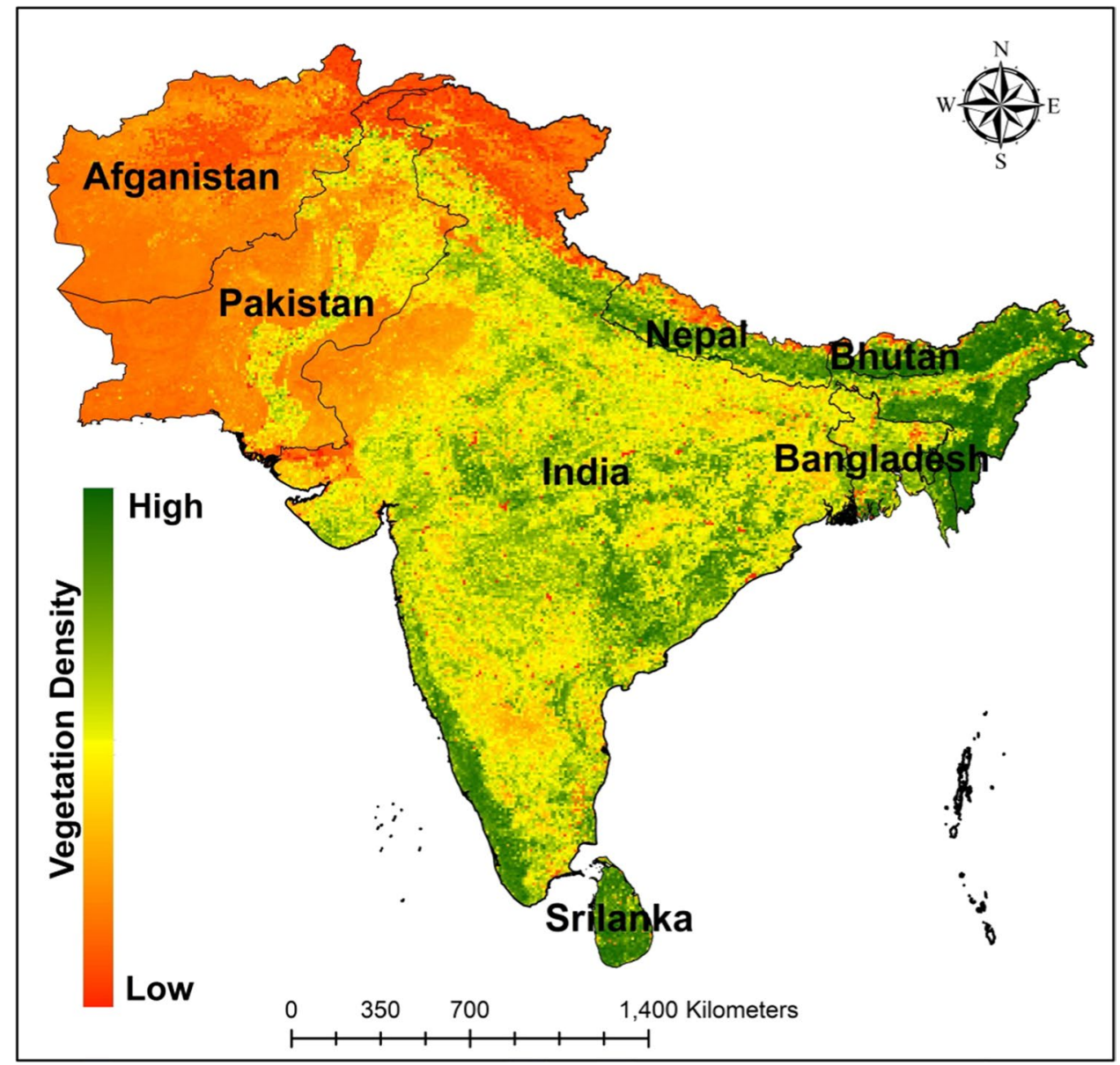

\subsubsection{NDVI Map}

The vegetation health as an indicator of land potentiality can be adequately monitored using satellite-based remote sensing derived products such as Normalized Difference Vegetation Index (NDVI) map (Gomes et al. 2017; Meneses-Tovar 2011). Such a product was significantly used for modeling (Lopresti et al. 2015; Li et al. 2013; Zomer et al. 2007). The soil erosion was found inversely proportional to NDVI values (Duran et al. 2008). The NDVI map for the study area is given in Fig. 3.

\subsubsection{Temperature, Precipitation and Aridity Map}

The growth of plant species is influenced by climate parameters (Hatfield et al. 2008, 2011). Such climate themes (temperature map: Fig. 4: precipitation map: Fig. 5) are crucial for land evaluation (FAO, 1976) and were utilized for agroforestry suitability mapping (Ritung et al. 2007). The Aridity Index (AI) is an indicator of the degree of dryness of the climate that was first proposed by UNEP (1997) and suitably quantified at the global level.
Such a parameter (aridity map: Fig. 6) can be utilized to support studies related to sustainable development/biodiversity/environmental conservation (Zomer et al. 2008; Trabucco et al. 2008) and agroclimatic zonation (Haftom et al. 2019).

\subsubsection{Slope Maps}

Arc GIS Software has several modules for data processing used in several applications. The surface sub-module was used for the production of a slope map from GTOPO30 data (Fig. 7). GTOPO30 data are suitable for many applications including climate and hydrologic modeling at regional and continental scale (Grohmann 2016). Vegetation growth, distribution and spatial pattern largely depend on the topographical variation (Bunyan et al. 2015).

\subsubsection{Agroforestry Suitability Mapping}

GIS software with modeling tools provides the opportunity to edit, reclassify, analyze and pool different thematic 
Fig. 4 Mean annual temperature

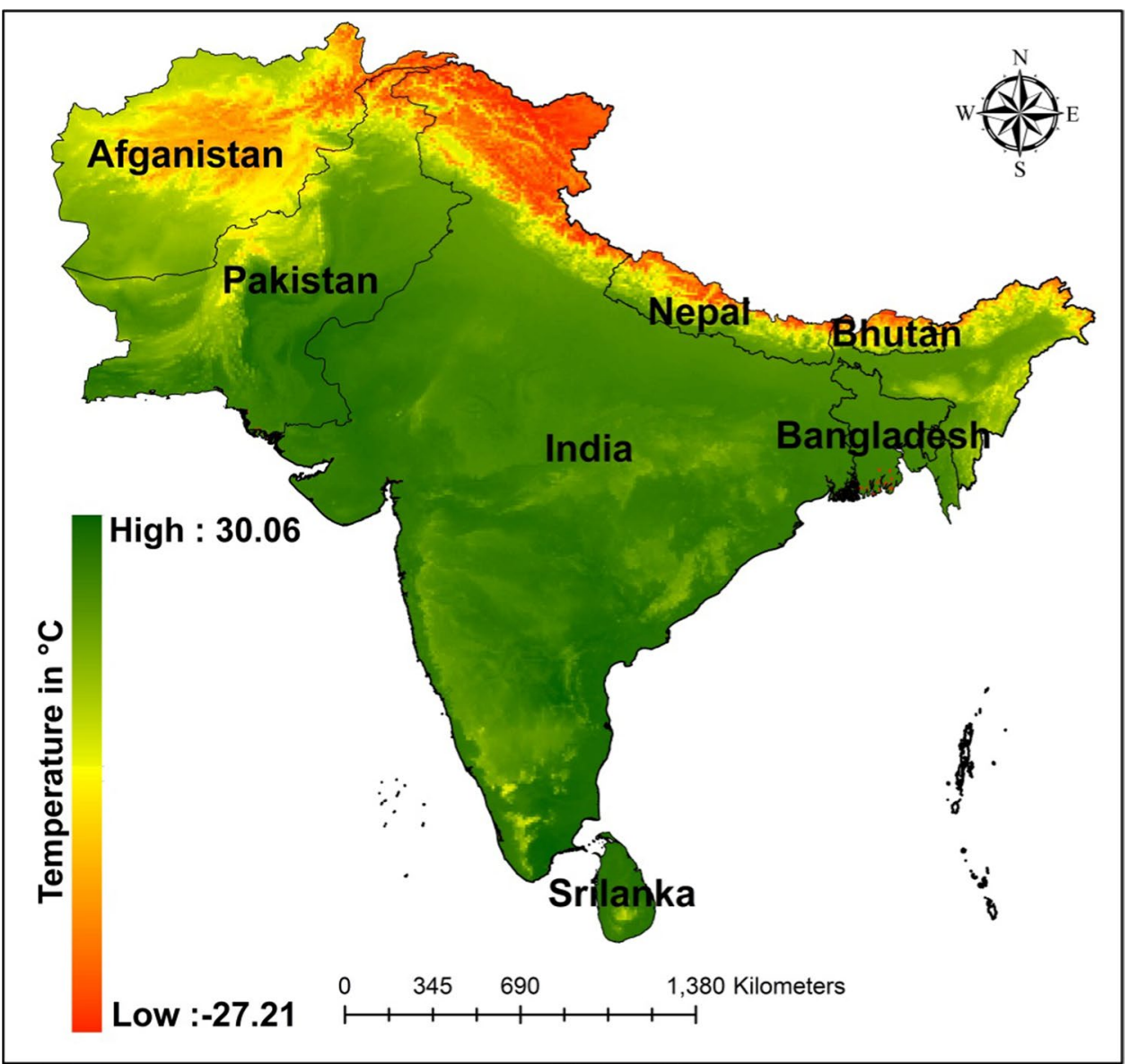

layers and facilitate integration with RS data. We have integrated the diversified datasets of land, climate, topography and soil (Fig. 8) based on their importance and weight factor (Table 2: land requisites for agroforestry utility) to achieve the agroforestry suitability mapping. Land requisites for agroforestry utility have been developed logically with expert-knowledge using the guidelines provided by FAO (1976). The integrated map was reclassified into various suitability groups which are given in Fig. 9.

\subsubsection{Tree Cover Analysis}

The representative tree cover analysis, extent and geographical distribution patterns in the agroforestry landscape are crucial (Zomer et al. 2009). Tree cover percent is an important component in the agroforestry system which was evaluated at the sub-continental level and its spatial extent was examined. In the first step, the tree cover percent data were mosaicked, various raster tree cover grid value was brought into various percent categories. Furthermore, the tree cover percent dataset was examined with respect to the total geographical area, agriculture land area as well as at the various agroforestry suitability categories to understand its distribution paradigm.

\section{Results and Discussion}

\subsection{Land Suitability Investigation for Agroforestry}

The final land suitable map was used to extract zonal statistics for agroforestry in South Asia, and the results are depicted in Table 3 and Fig. 9. The 470,223.3 (9.11\%), $1,416,820.5(27.46 \%)$ and 2,907,351.1 (56.34\%) of area $\left(\mathrm{km}^{2}\right)$ are found low $(<35 \%)$, medium $(35-65 \%)$, and high ( $\geq 65 \%$ ) suitable, respectively, for agroforestry. The not suitable area $\left(\mathrm{km}^{2}\right)$ is found to be $365,929.9(7.09 \%)$ due to constraints of cultivation. Furthermore, approximately $69 \%$ of the total geographical area retains $55 \%$ and greater suitability for agroforestry. The total agriculture area (Tateishi et al. 2011) was reported as approximately $51.6 \%$ of the total geographical land area (excluding the not suitable area: Table 2), whereas significantly high percent (76\%) of these areas is found to be highly suitable $(\geq 65 \%)$ for agroforestry (Table 3). 
Fig. 5 Mean annual precipitation

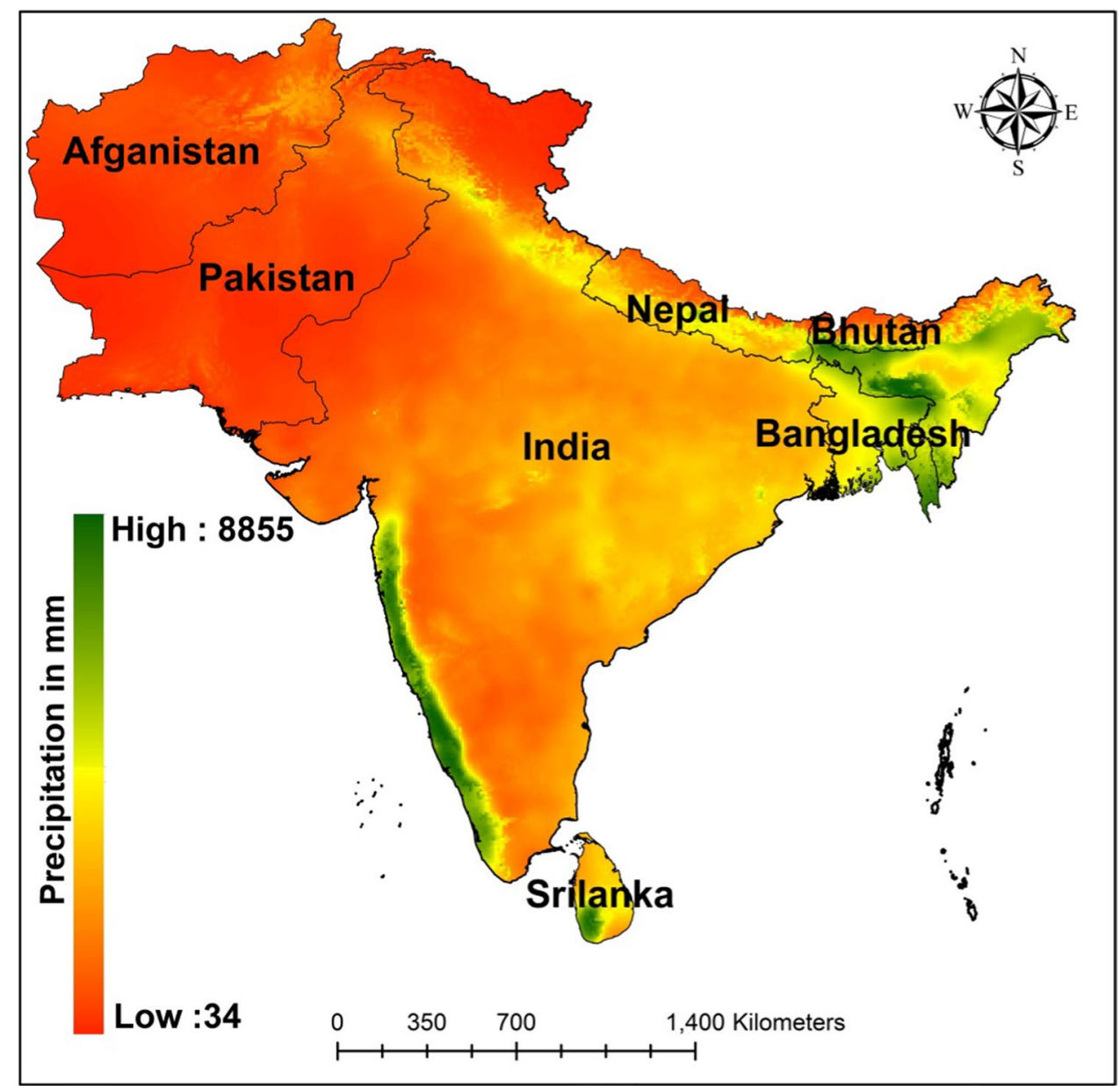

The few regions such as coastal, northeast and Himalayan landscape of South Asia manifested high agroforestry suitability categories because of the significant climate and biophysical suitability towards plant growth. The northwest parts of the South Asian region are mostly having less than $25 \%$ agroforestry suitability categories due to low soil fertility, low precipitation and dry environment (low aridity index values). Additionally, we have evaluated the country-wise agroforestry suitability which is given in the supplementary section.

\subsection{Tree Cover Analysis}

The various tree cover percent categories in the year 2000 of South Asia are given in Fig. 10 and in Table 4. The tree cover absent $(0 \%)$ and tree cover $1-10 \%$ areas are approximately $73.4 \%$ and $7.1 \%$ respectively, of the total land area. Tree cover percent greater than $10 \%$ (which represents the forest as per definition by FAO 2010) occupied $19.5 \%$ of the total geographical area. Our result coincides significantly with the result of forest percent $(18.6 \%)$ claimed by FAO in the same year which excluded Afghanistan, but included the Maldives (FAO 2001).

Here, we have investigated the tree cover dominance with reference to various agroforestry suitability categories which are given in Table 5. The tree cover percent category 1-10\% occupied $340,955.9 \mathrm{~km}^{2}$ which is $7.01 \%$ of the total geographical area of South Asia, whereas out of which approximately $0.81 \%, 6.17 \%$, and $22.17 \%$ falls in the agroforestry categories low $(<35 \%)$, medium $(35 \%-65 \%)$, and high ( $\geq 65 \%$ ) suitability, respectively (Table 5). This result also highlights high agroforestry suitability categories although retain high tree cover percent (Table 5). Furthermore, tree cover percent can be increased significantly in land potential areas. The majority of rural people/farmers of South Asian countries suffering from poverty (Thapa 2004) depend on monsoon rain for agriculture activity, whereas frequent flood, drought, and abrupt rainfall patterns (climate change impact) hinder their major occupation significantly resulting into crop failure (Carleton 2017). The agroforestry practices based on land suitability with appropriate soil and conservation practices utilizing the watershed approach (Bhan 2013; Birhanu et al. 2018) will provide adequate soil moisture that 
Fig. 6 Annual aridity

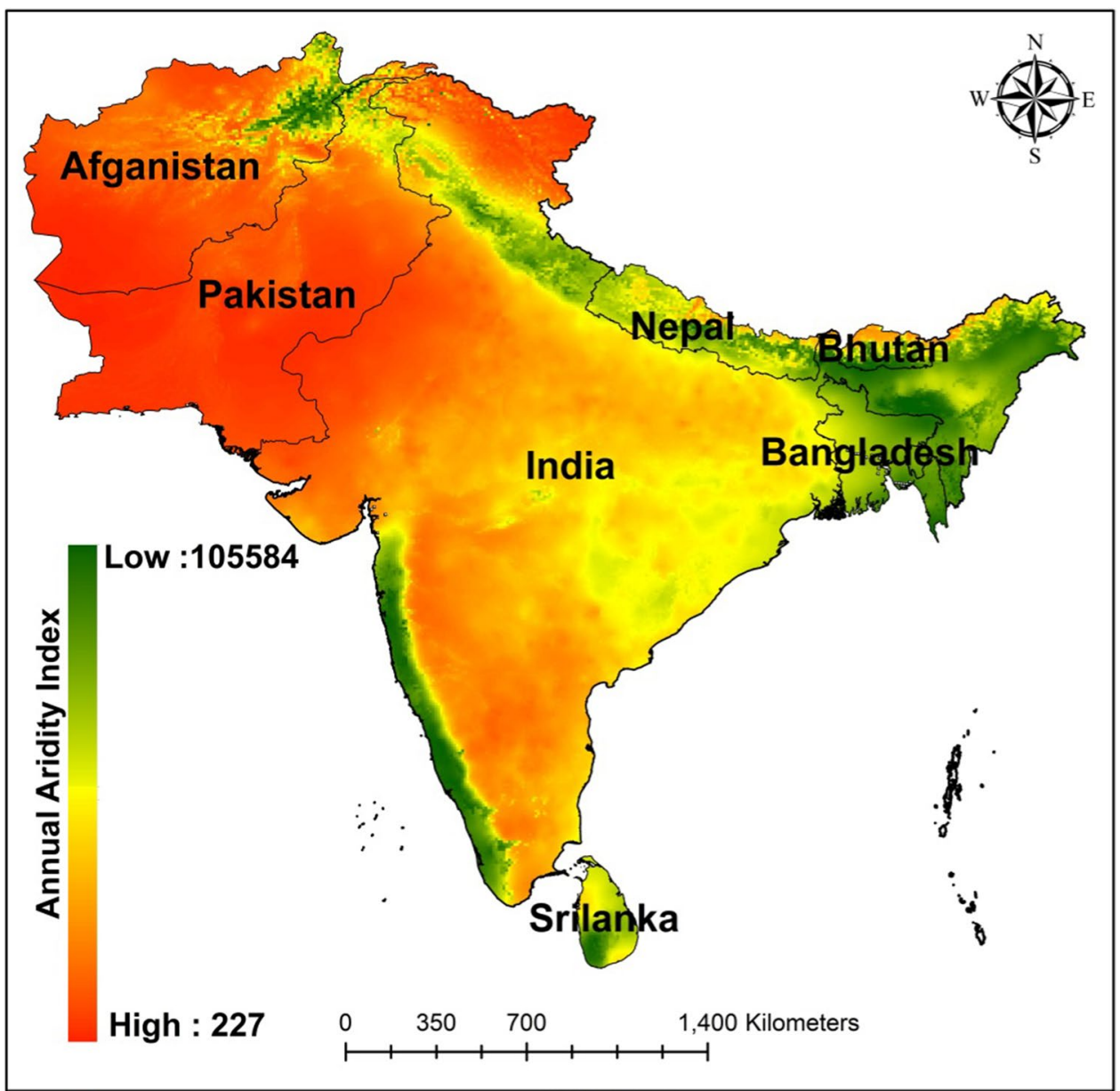

will support the crops even in the dryland area and withstand in severe weather conditions. Such scientific and skillful utilization of land is a feasible solution for the cultivators/farmers who have the capacity to raise their income by several folds and can achieve the socio-economic and environmental goals of the society in a sustainable manner (Ahmad et al. 2019). Our investigation manifested the scope to exploit various agroforestry practices in South Asia in the agriculture land keeping in mind of land potentiality by analyzing the topography and ecological condition which suit various tree crops locally as per farmer needs (Iiyama et al. 2016) in participatory approach (Bayala et al. 2018) for enhancing tree cover significantly.

\subsection{Tree Covers Hot Spot Analysis in the Agroecosystem}

The tree cover analysis in the agroforestry system was widely discussed in the past but was not evaluated accurately in the agriculture landscape due to the unavailability of adequate datasets. We have utilized the cropland mask
(Thenkabail et al. 2016) and created tree cover hotspots within the agriculture ecosystem. The areas represented by high tree cover percent value (red color) are $3.4 \%$ of the total agriculture ecosystem. The major high dominance of tree cover hotspot areas is marked from 1 to 5 in Fig. 11. The result highlights that the tree cover is notably high along the coast of Western Ghats of peninsular India which retains rice-based agroforestry practices including several home gardens (complex sustainable land-use system which include multiple farming components) with dominant tree crop of coconut, rubber plantation mixing significantly in traditional agroforestry system (Kumar 1999; Kumar and Takeuchi 2015). Similarly, the tree hotspot was observed and found noticeable in the northeast of the study area including the Brahmaputra plain of India, Bangladesh (Leuschner and Khaleque 1987) and in the south of study area in Sri Lanka (Ranashinghe and Newman 1993). The agroforestry system manifesting tree covers is also prominent in some places of the south of the state of Gujarat, northwest Tamil Nadu and in few places of Indo-Gangetic Plain of India. 
Fig. 7 Slope map

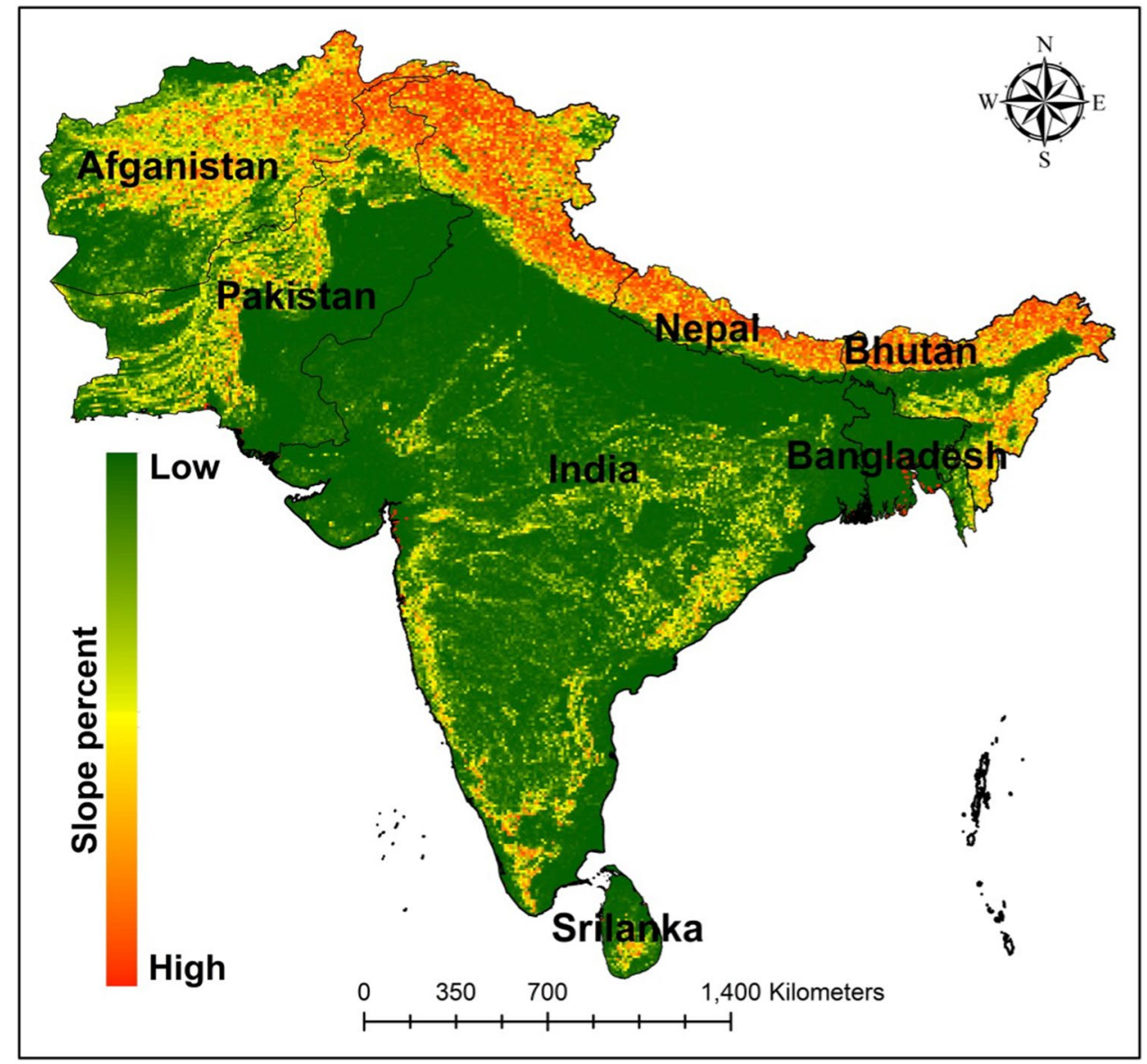

Fig. 8 Flowchart for agroforestry suitability mapping

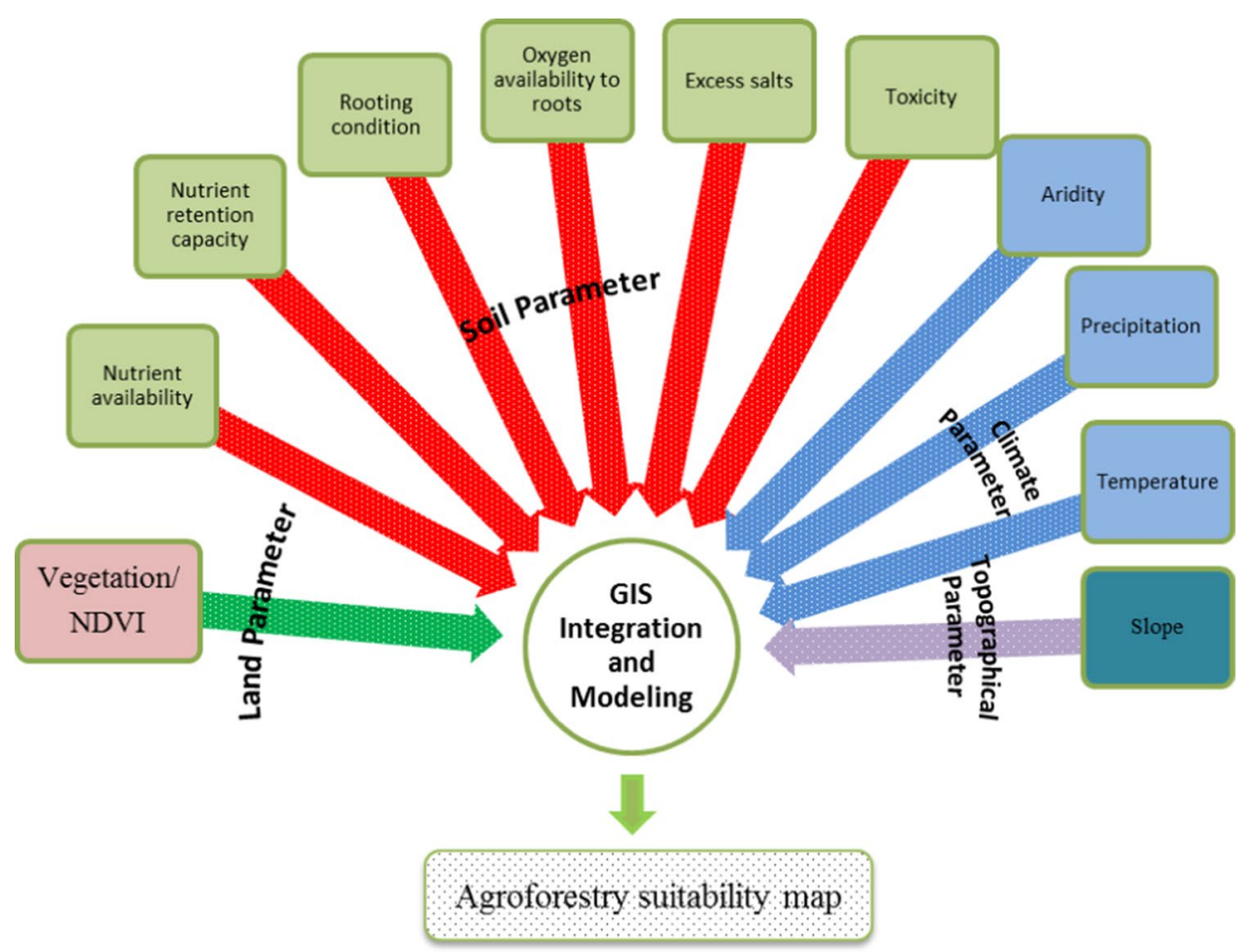


Table 2 Land requisites for agroforestry utility

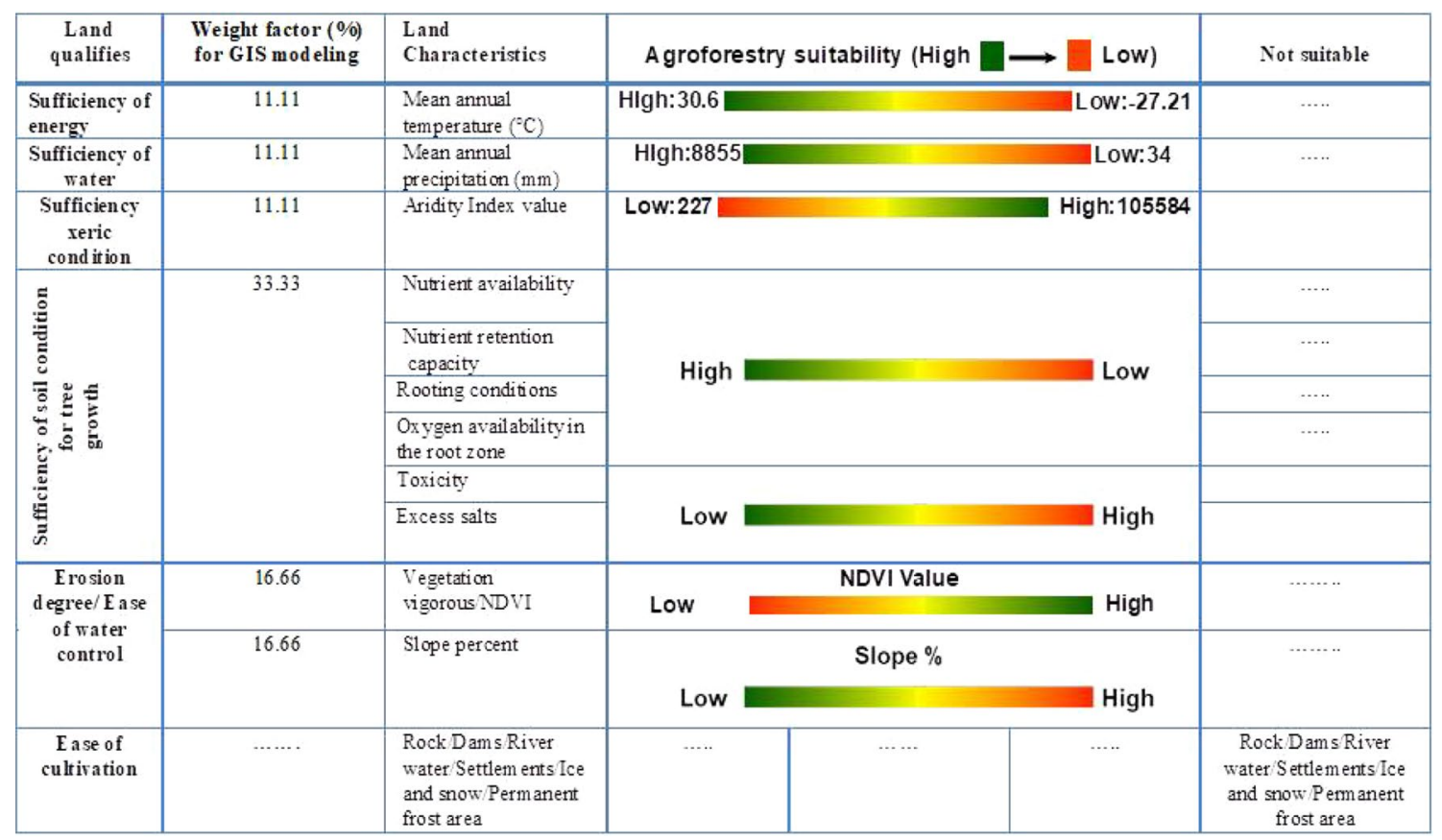

Fig. 9 The overall land potential map for the general suitability of the growing trees in South Asia

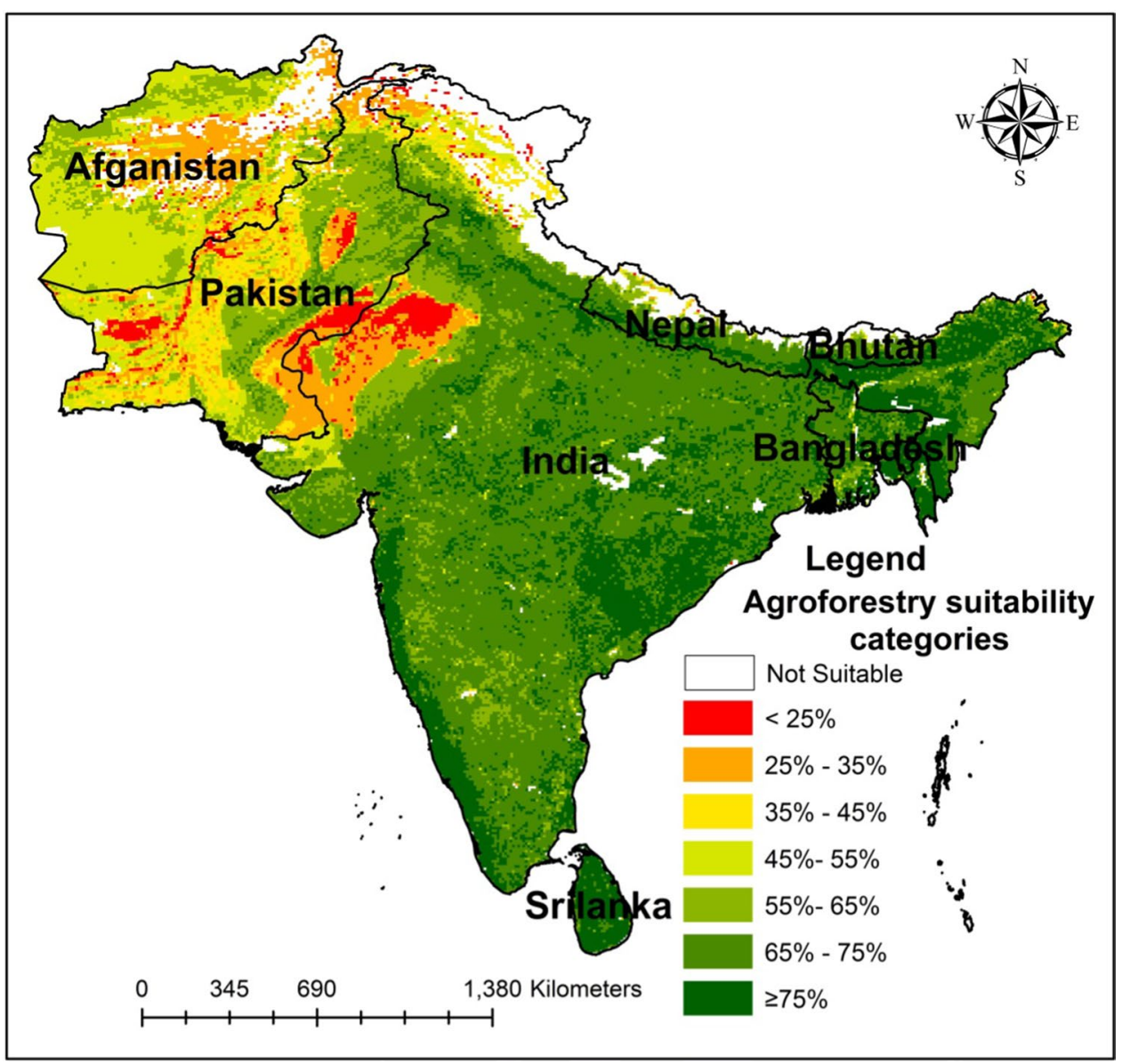


Table 3 Land fitness statistics for agroforestry utility

\begin{tabular}{lllc}
\hline Agroforestry suitability & Cropland area $\left(\mathrm{km}^{2}\right)$ & Total area $\left(\mathrm{km}^{2}\right)$ & Total area percent \\
\hline Not suitable & - & $365,929.9$ & 7.09 \\
$<25 \%$ & $30,011.1$ & $121,929.3$ & 2.36 \\
$25-35 \%$ & $73,760.3$ & $348,294.0$ & 6.75 \\
$35-45 \%$ & $18,505.7$ & $272,126.4$ & 5.27 \\
$45-55 \%$ & $57,669.4$ & $471,475.4$ & 9.14 \\
$55-65 \%$ & $398,260.0$ & $673,218.7$ & 13.05 \\
$65-75 \%$ & $1,566,858.4$ & $2,040,794.0$ & 39.55 \\
$\geq 75 \%$ & $329,934.2$ & $866,557.1$ & 16.79 \\
Total $\left(\mathrm{km}^{2}\right)$ & $2,474,999.1$ & $5,160,325$ & 100.00 \\
\hline
\end{tabular}

Fig. 10 Tree cover percent map of South Asia

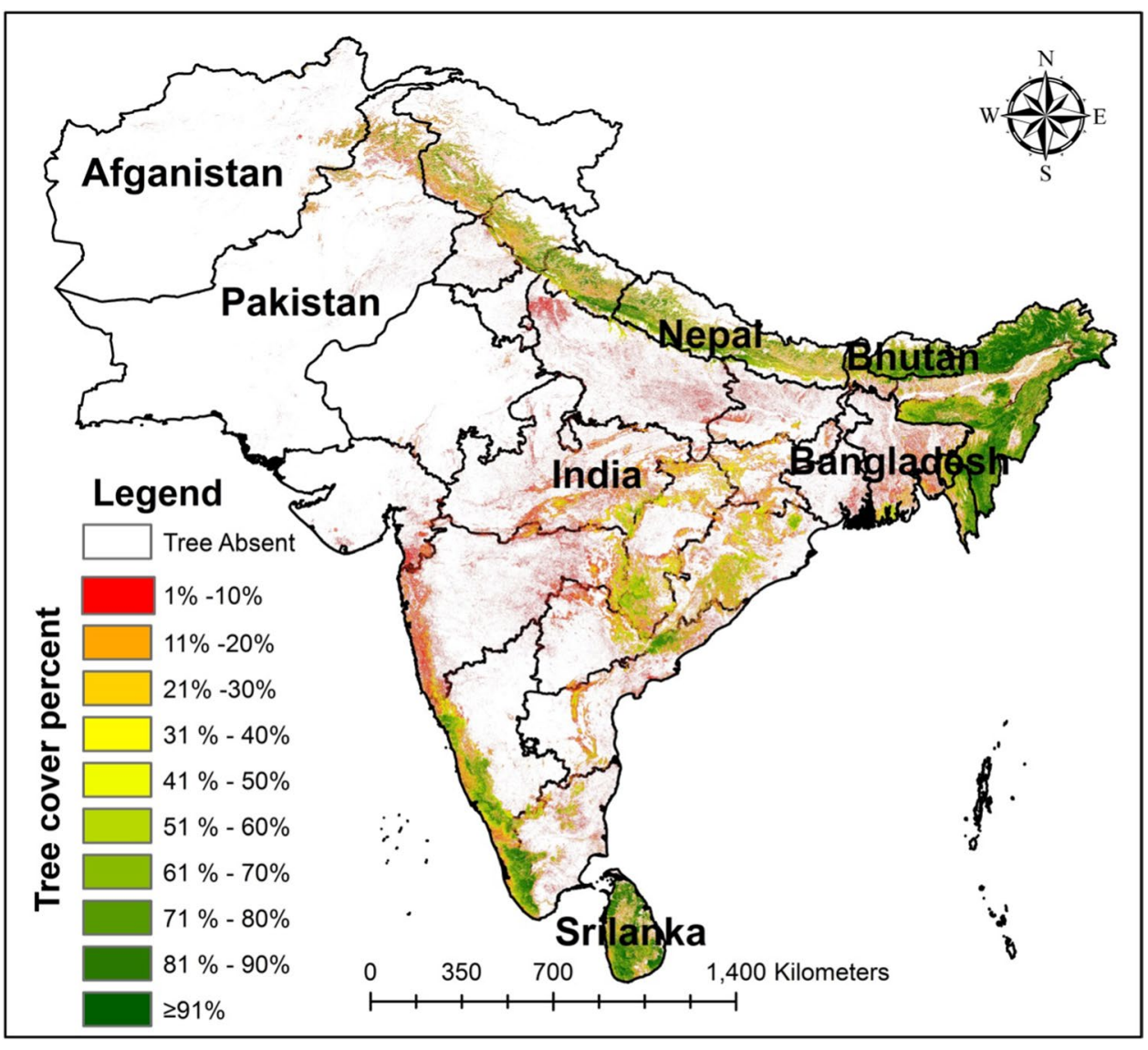

\subsection{Potential Agroforestry Within Farming Systems}

In this part of the study, we have examined the spatial relationship using the ArcGIS complex query to understand the distribution of Agroforestry suitability/tree cover percent in various agriculture crop categories in farmland (Table 6 and Fig. 12). The evaluation revealed that the total cropland area in South Asia was 2,475,204 km². The single crop, double-crop, triple-crop, and rainfedcrop were found to be approximately $56.6 \%, 30.0 \%, 1.6 \%$, and $11.8 \%$, respectively. The single cropland category manifested $8.4 \%$ of the total area has less than equal to $10 \%$ tree cover percentage. Additionally, this category retains a large area which is found to be highly suitable towards agroforestry (Table 6). There are various options that can be utilized to increase tree dominance in diversified agroforestry practices like watershed-based soil and/or water conservation, nutrient management, and crop management. Approximately $73 \%$ of the rainfed area showed agroforestry suitability greater than $50 \%$ which gives adequate opportunity to harness agroforestry practices such as the silivi-pastoral system with better soil management 
Table 4 Tree covers percent statistics

\begin{tabular}{llc}
\hline Tree cover \% & Total area $\left(\mathrm{km}^{2}\right)^{\mathrm{a}}$ & Total area ${ }^{\mathrm{a}}$ \\
\hline Tree absent & $3,517,344$ & 73.36 \\
$1-10 \%$ & $340,955.9$ & 7.11 \\
$11-20 \%$ & $112,127.7$ & 2.34 \\
$21-30 \%$ & $85,274.19$ & 1.78 \\
$31-40 \%$ & $76,759.94$ & 1.60 \\
$41-50 \%$ & $83,947.32$ & 1.75 \\
$51-60 \%$ & $99,738.54$ & 2.08 \\
$61-70 \%$ & $96,460.3$ & 2.01 \\
$71-80 \%$ & $113,205.9$ & 2.36 \\
$81-90 \%$ & $190,225.2$ & 3.97 \\
$\geq 91 \%$ & $78,355.82$ & 1.63 \\
Total area ${ }^{\mathrm{a}}\left(\mathrm{km}^{2}\right)$ & $4,794,394.9$ & 100.00 \\
\hline
\end{tabular}

${ }^{\mathrm{a}}$ Total area/percent (excluding the not suitable agroforestry category)

practices (Garcia-Franco et al. 2018). Such an effort will intensify the tree cover percent in the long run. Additionally, we have examined the country-wise tree cover $\%$ area in farmlands, agroforestry suitability and tree cover distribution in different categories of Agro-ecological Zones (AEZ) in South Asia are given in the supplementary section.

\subsection{Climate Change Influence on Farming}

Farming practices contribute significantly to the rural economy of South Asia and provide diversified jobs to the majority of the poor population (Thapa 2004). Climate change footprints are well recognized in the agriculture and have tremendously threatened the livelihood of farmers (Lewis et al. 2018). The frequent droughts/variations in rainfall patterns/increase in temperature (Dash et al. 2007) have consequently reduced the agriculture output which has been a serious policy concern in this region (Mendelsohn 2014).

The predicted (2030) precipitation anomaly map produced and overlaid with the present decadal (2006-2015) precipitation deficit [obtained by comparing with 20 years back decadal precipitation data (1976-1985)] is given in Fig. 13. The present decadal precipitation deficit is found significant over the large part of South Asian countries whereas it is more crucial for India. The Indo-Gangetic plains, the part of coastal ecosystems of India which are known for rice/wheat/home garden growing area will be largely affected. Furthermore, a large part of the present precipitation deficit area will experience the precipitation deviation in the future (2030) (Fig. 13) which will be a big challenge for policymakers as far as food production is concerned. The precipitation anomaly range (in $\mathrm{mm}$ ) over South Asia in the year 2030 was found from - (decrease) 28.27 to + (increase) 240.74. Similarly, the temperature increase was found very significant in the whole of South Asia with a range of 0.53 to $1.40{ }^{\circ} \mathrm{C}$ (Fig. 14). The temperature increase was quite visible in India and Afghanistan. It is noticeable in the northern and northeastern regions of India. The medium increase was observed in the northwestern region of Pakistan and the central region of India. In one of the studies, it was well established that by each degree rise of temperature will significantly reduce the average yield (3.1-7.4) in some of the important agricultural crops (Zhao et al. 2017). Finally, we can summarize that the climate change influence will be more pronounced in the South Asian subcontinent, whereas it is more crucial for the country India (Mendelsohn 2014) which will certainly impact the future crop production scenario. There is a

Table 5 Agroforestry suitability categories vs. tree cover \% statistics

\begin{tabular}{|c|c|c|c|c|c|c|c|c|}
\hline \multirow[t]{2}{*}{ Tree cover $\%$} & \multicolumn{7}{|c|}{ Agroforestry suitability categories (\%) } & \multirow[t]{2}{*}{ Total area $\left(\mathrm{km}^{2}\right)$} \\
\hline & $<25 \%$ & $25-35 \%$ & $35-45 \%$ & $45-55 \%$ & $55-65 \%$ & $65-75 \%$ & $\geq 75$ & \\
\hline Tree absent & 99.674 & 98.950 & 96.655 & 96.308 & 89.659 & 66.530 & 43.015 & $3,517,344$ \\
\hline $1-10 \%$ & 0.216 & 0.592 & 1.450 & 1.110 & 3.609 & 9.627 & 12.542 & $340,955.9$ \\
\hline $11-20 \%$ & 0.041 & 0.153 & 0.494 & 0.448 & 1.083 & 2.817 & 4.998 & $112,127.7$ \\
\hline $21-30 \%$ & 0.020 & 0.086 & 0.310 & 0.334 & 0.800 & 2.136 & 3.872 & $85,274.19$ \\
\hline $31-40 \%$ & 0.013 & 0.057 & 0.226 & 0.280 & 0.671 & 1.924 & 3.557 & $76,759.94$ \\
\hline $41-50 \%$ & 0.010 & 0.045 & 0.191 & 0.274 & 0.664 & 2.046 & 4.124 & $83,947.32$ \\
\hline $51-60 \%$ & 0.008 & 0.036 & 0.170 & 0.277 & 0.664 & 2.298 & 5.362 & $99,738.54$ \\
\hline $61-70 \%$ & 0.006 & 0.031 & 0.157 & 0.277 & 0.685 & 2.351 & 4.850 & $96,460.3$ \\
\hline $71-80 \%$ & 0.007 & 0.027 & 0.159 & 0.310 & 0.835 & 3.002 & 5.116 & $113,205.9$ \\
\hline $81-90 \%$ & 0.004 & 0.021 & 0.157 & 0.333 & 1.134 & 5.380 & 8.161 & $190,225.2$ \\
\hline$\geq 91 \%$ & 0.000 & 0.002 & 0.032 & 0.049 & 0.198 & 1.889 & 4.402 & $78,355.82$ \\
\hline Total area $\left(\mathrm{km}^{2}\right)$ & $121,929.3$ & 348,294 & $272,126.4$ & $471,475.4$ & $673,218.7$ & $2,040,794$ & $866,557.1$ & $4,794,394.9$ \\
\hline
\end{tabular}


Fig. 11 Tree cover hotspot map in the agriculture landscape of South Asia
Table 6 Agroforestry suitability and tree cover evaluation in farmland

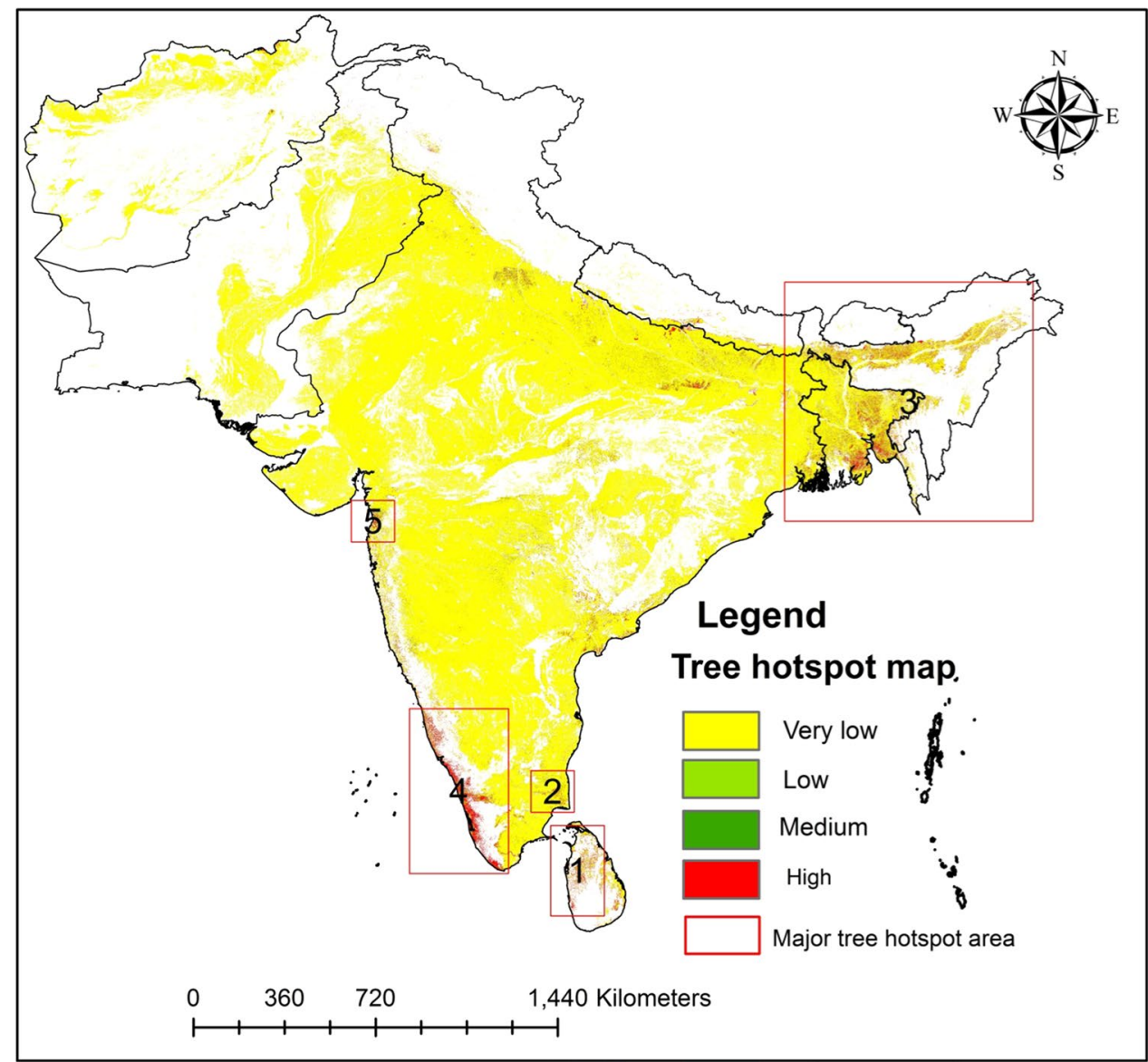

\begin{tabular}{lllll}
\hline Agroforestry suitability & \multicolumn{2}{l}{ Irrigated croplands } & Rainfed croplands \\
\cline { 2 - 3 } & Single crop & Double crop & $\begin{array}{l}\text { Triple/continu- } \\
\text { ous crop }\end{array}$ & Rainfed crop \\
\hline & \multicolumn{2}{l}{ Agricultural crop phenology } & & \\
\hline $30 \%$ & 11,298 & 14,204 & 139 & 54,808 \\
$30-50 \%$ & 7363 & 19,912 & 138 & 23,039 \\
$50-70 \%$ & 38,735 & 367,410 & 8053 & 161,107 \\
$\geq 70 \%$ & $1,344,391$ & 340,462 & 30,489 & 53,656 \\
Total area $\left(\mathrm{km}^{2}\right)$ & $1,401,787$ & 741,988 & 38,819 & 292,610 \\
Tree cover $\%$ & Agricultural crop area percent & & \\
Tree absent & 87.9 & 92.1 & 77.6 & 92.3 \\
$\leq 10 \%$ & 8.4 & 6.9 & 13.0 & 4.6 \\
$>10 \%$ & 3.7 & 1.1 & 9.4 & 3.2 \\
& 100.0 & 100.0 & 100.0 & 100.0 \\
\hline
\end{tabular}

need to orient the farming practices with a new scheme/program to sustain the climate change influence (Lipper et al 2014). Introducing the agroforestry practice in the potential area will provide a vital and viable solution in South Asia because it has the capacity to withstand the intense weather phenomenon in the future (NAP 2014).

\section{Conclusion}

This study analyzed the various remote sensing-based global data sets and integrated/modeled in the GIS domain for achieving the agroforestry suitability, tree cover percent, tree cover hotspot (in agriculture) mapping. Furthermore, these 
Fig. 12 Agroforestry potential areas within croplands of South Asia

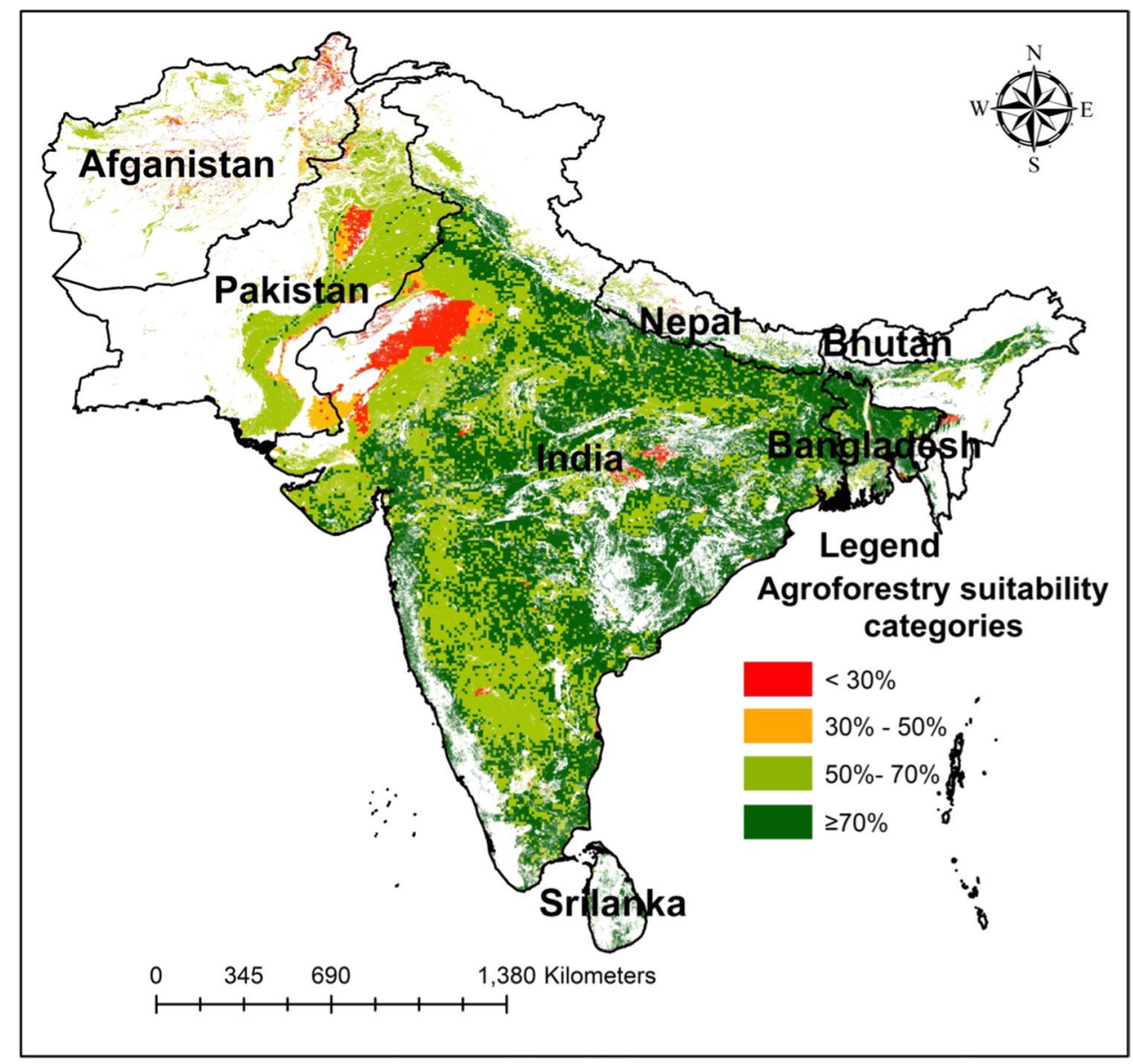

maps were utilized to investigate the spatial relationship critically to address some of the important research gaps. Computer-oriented scientific evaluation of global datasets of various themes and its judicious analysis/investigation greatly support in the policy-driven process.

Poverty is very significant in South Asia whereas it is more pronounced in the rural areas. The majority of the people/farmers in Southeast Asia live in rural areas who have a weak socioeconomic condition and largely depend on the agricultural practices for their livelihood are currently threatened due to the adverse effects of climate change. Adopting agroforestry by South Asian people/farmers is a sensible solution for achieving sustainability by optimizing the farmland for diversified output for fulfilling the demand of food, nutrition, energy, and employment.

In our study, it was found the approximately two-thirds of geographical area of South Asia has land potentiality greater than $55 \%$ towards agroforestry, whereas nearly four-fifths of the geographical land has nil $(0 \%)$ tree cover. The evaluation within the farming system highlights the single crop occupies approximately $56.6 \%$ of total farming area and retains nearly $12 \%$ of the area greater than $1 \%$ tree cover but has far high cropland potentiality towards agroforestry suitability. 
Fig. 13 Precipitation anomaly

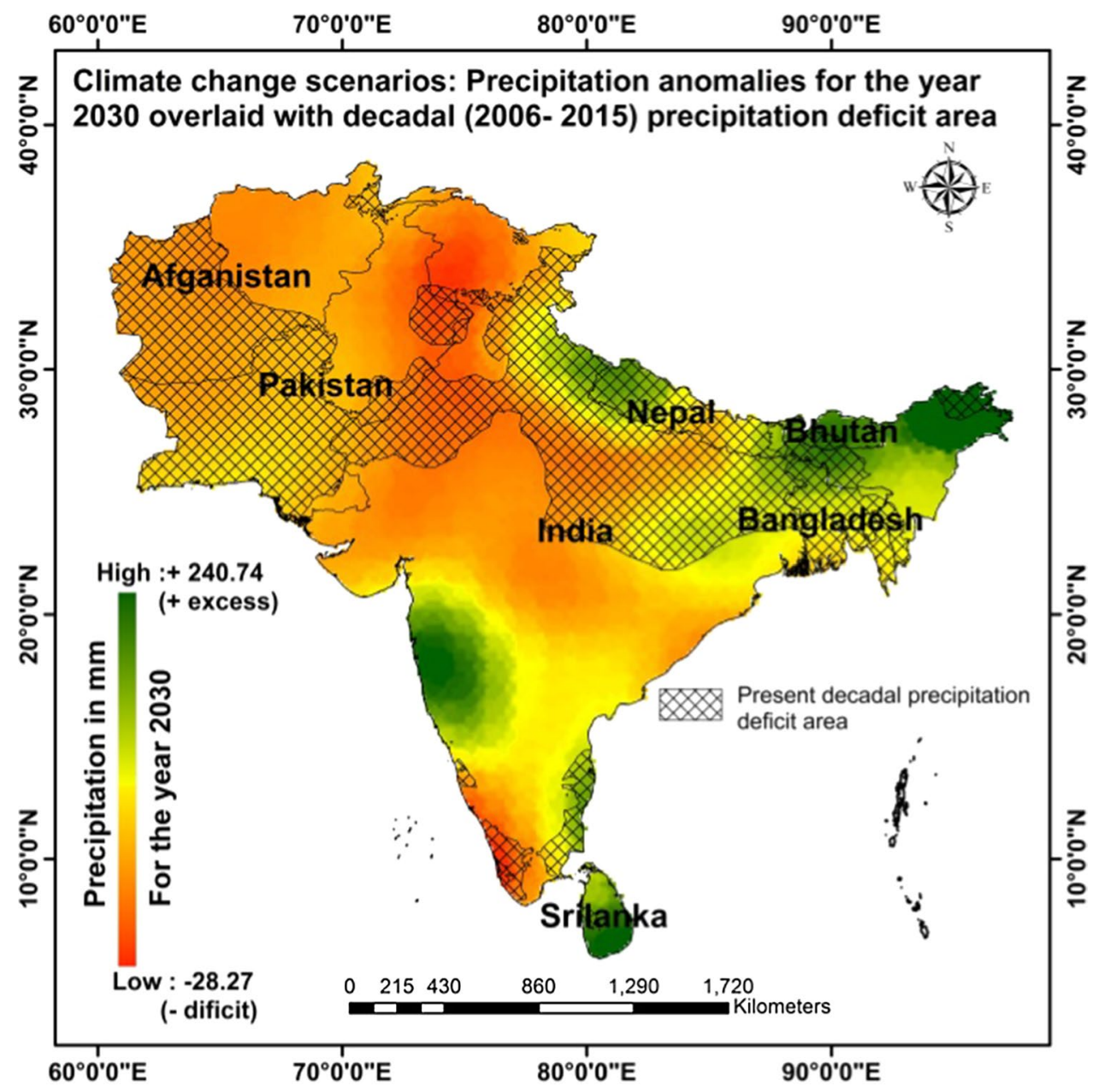

The future (2030) prediction of annual climate (precipitation and temperature) anomalies map also showed a significant spatial varying pattern over South Asia which will impact future crop production scenario is a matter of concern.

This result/analysis provides immense scope to exploit the identified potential land area for agroforestry uses and supports the policymakers of this subcontinent for further expansion in the future. The farmers of South Asian countries are small landowners and a large percent of them depend on monsoon rains for agriculture activities. Due to inadequate irrigation facilities in the off monsoon period, they are unable to cultivate in the land. Thus, there is a need to address this issue based on the conservation of seasonal rainwater. This approach will enhance land soil moisture for a longer span which will tremendously magnify the crop output (Ahmad and Goparaju 2017).

This research has its own importance because agroforestry suitability, tree cover percent, tree cover hot spot (agriculture landscape), future climate prediction mapping and the spatial relationships (GIS complex Query) among them have been investigated for the first time in the South Asian subcontinent level and analyzed meaningfully. 
Fig. 14 Temperature anomaly

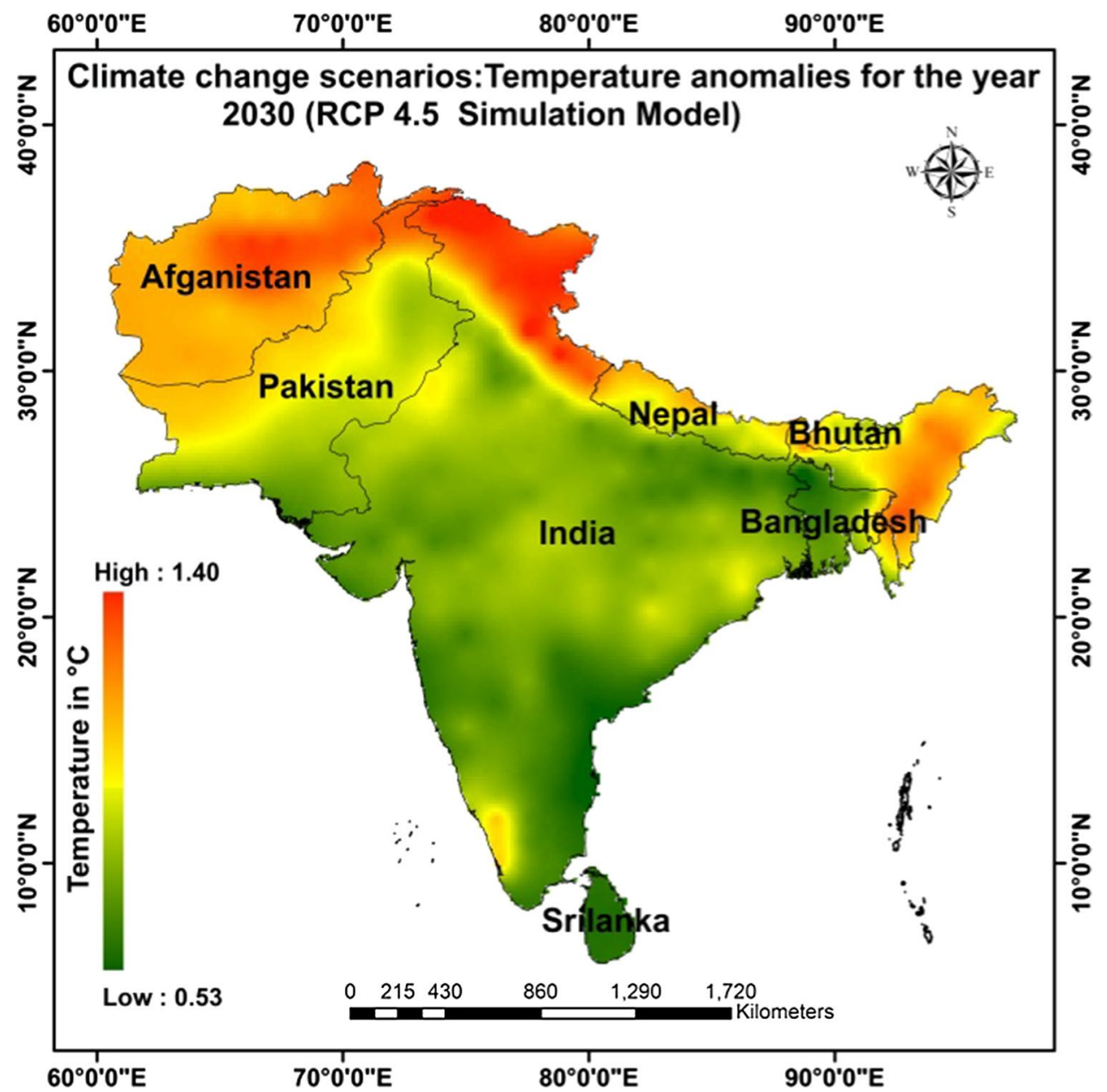

Open Access This article is licensed under a Creative Commons Attribution 4.0 International License, which permits use, sharing, adaptation, distribution and reproduction in any medium or format, as long as you give appropriate credit to the original author(s) and the source, provide a link to the Creative Commons licence, and indicate if changes were made. The images or other third party material in this article are included in the article's Creative Commons licence, unless indicated otherwise in a credit line to the material. If material is not included in the article's Creative Commons licence and your intended use is not permitted by statutory regulation or exceeds the permitted use, you will need to obtain permission directly from the copyright holder. To view a copy of this licence, visit http://creativecommons.org/licenses/by/4.0/.

\section{References}

Ahmad F, Goparaju L (2017) Land evaluation in terms of agroforestry suitability, an approach to improve livelihood and reduce poverty: a FAO based methodology a geospatial solution: a case study of Palamu district, Jharkhand, India. Ecol Quest 25:67-84. https:// doi.org/10.12775/EQ.2017.006

Ahmad F, Uddin MM, Goparaju L (2019) Agroforestry suitability mapping of India: geospatial approach based on FAO guidelines. Agrofor Syst 93(4):1319-1336. https://doi.org/10.1007/s1045 7-018-0233-7
Aldhous P (2004) Land remediation: Borneo is burning. Nature 432:144-146. https://doi.org/10.1038/432144a

Bayala J, Dayamba SD, Ayantunde AA, Somda J, Ky-Dembele C, Bationo BA, Buah S, Sanogo D, Tougiani A, Zougmore R (2018) METHODOLOGICAL GUIDE: community participatory inventory and prioritization of climate smart crop-livestock-agroforestry technologies/practices. ICRAF Technical Manual. World Agroforestry Centre, Nairobi

Bhan S (2013) Land degradation and integrated watershed management in India. Int Soil Water Conserv Res 1(1):49-57. https:// doi.org/10.1016/S2095-6339(15)30049-6

Birhanu BZ, Traoré K, Gumma MK et al (2018) A watershed approach to managing rainfed agriculture in the semiarid region of southern Mali: integrated research on water and land use. Environ Dev Sustain. https://doi.org/10.1007/s 1066 8-018-0144-9

Bloom DE, Rosenberg L (2011) The Future of South Asia: population dynamics, economic prospects, and regional coherence. WDA-Forum, University of St. Gallen, St. Gallen

Bunyan M, Bardhan S, Aditya S, Jose S (2015) Effect of topography on the distribution of tropical montane forest fragments: a predictive modeling approach. J Trop For Sci 27(1):30-38. https ://www.jstor.org/stable/43150972

Carleton TA (2017) Crop-damaging temperatures increase suicide rates in India. PNAS 114(33):8746-8751. https://doi. org/10.1073/pnas.1701354114 
Chen Q, Lu D, Keller M, dos-Santos MN, Bolfe EL, Feng Y, Wang C (2016) Modeling and mapping agroforestry aboveground biomass in the brazilian amazon using airborne lidar data. Remote Sens 8(1):21. https://doi.org/10.3390/rs8010021

Danielson JJ, Gesch DB (2011) Global multi-resolution terrain elevation data 2010 (GMTED2010): US Geological Survey OpenFile Report 2011-1073

Dash SK, Jenamani RK, Kalsi SR, Panda SK (2007) Some evidence of climate change in twentieth-century India. Clim Change 85:299-321. https://doi.org/10.1007/s10584-007-9305-9

Dollinger J, Jose S (2018) Agroforestry for soil health agroforestry systems. Agrofor Syst 92:213-219. https://doi.org/10.1007/ s10457-018-0223-9

Duran ZVH, Rodriguez PCR, Francia MJR, Carceles RB, Martinez RA, Perez GP (2008) Harvest intensity of aromatic shrubs vs. soil-erosion: an equilibrium for sustainable agriculture (SE Spain). CATENA 73(1):107-116. https://doi.org/10.1016/j. catena.2007.09.006

Ellis EA, Bentrup G, Schoeneberger MM (2004) Computerbased tools for decision support in agroforestry: current state and future needs. Agrofor Syst 61(1):401-421. https://doi. org/10.1023/B:AGFO.0000029015.64463.65

FAO (1976) A framework for land evaluation. Soils Bulletin 32. Food and Agriculture Organization of the United Nations, Rome, Italy. ISBN 92-5-100111-1. https://www.fao.org/3/x5310 e/x5310e00.htm. Accessed 10 June 2018

FAO (2001) South Asia. https://www.fao.org/docrep/004/y1997e/ y1997e0s.htm. Accessed 10 June 2018

FAO (2010) Global Forest Resources Assessment 2010. https://www. fao.org/3/a-i1757e.pdf. Accessed 10 June 2018

FAO (2017) Agroforestry for landscape restoration. https://www.fao. org/3/b-i7374e.pdf. Accessed 10 Dec 2018

Fick SE, Hijmans RJ (2017) Worldclim 2: new 1-km spatial resolution climate surfaces for global land areas. International Journal of Climatology. https://worldclim.org/version2. Accessed 10 June 2018

Fischer G, Nachtergaele F, Prieler S, van Velthuizen HT, Verelst L, Wiberg D (2008) Global agro-ecological zones assessment for agriculture (GAEZ 2008). IIASA, Laxenburg, Austria and FAO, Rome, Italy. https://www.fao.org/soils-portal/soil-survey/soilmaps-and-databases/harmonized-world-soil-database-v12/soilqualities-data/en/. Accessed 10 June 2018

Garcia-Franco N, Hobley E, Hubner R, Wiesmeier M (2018) Climatesmart soil management in semiarid regions, soil management and climate change, 349-68. Elsevier, Amsterdam. https://doi. org/10.1016/B978-0-12-812128-3.00023-9

Gomes ACC, Bernardo N, Alcantara E (2017) Accessing the southeastern Brazil 2014 drought severity on the vegetation health by satellite image. Nat Hazards 89:1401. https://doi.org/10.1007/ s11069-017-3029-6

Goswami BN, Venugopal V, Sengupta D, Madhusoodanam MS, Xavier PK (2006) Increasing trends of extreme rain events over India in a warming environment. Science 314:1442-1445. https://doi. org/10.1126/science. 1132027

Grohmann CH (2016) Comparative analysis of global digital elevation models and ultra-prominent mountain peaks. ISPRS Ann Photogramm Remote Sens Spat Inf Sci III-4:17-23. https://doi. org/10.5194/isprs-annals-III-4-17-2016

Haftom H, Haftu A, Goitom K, Meseret H (2019) Agro-climatic zonation of Tigray region of Ethiopia based on aridity index and traditional agro-climatic zones. J Agrometeorol 21:176-181

Hansen MC, Potapov PV, Moore R, Hancher M, Turubanova SA, Tyukavina A, Thau D, Stehman SV, Goetz SJ, Loveland TR, Kommareddy A, Egorov A, Chini L, Justice CO, Townshend JRG (2013) High-resolution global maps of 21st-century forest cover change. Science 342(6160):850-853. https://doi.org/10.1126/ science. 1244693
Hatfield JL, Boote KJ, Fay P, Hahn L, Izaurralde RC, Kimball BA, Mader T, Morgan J, Ort D, Polley W, Thomson A, Wolfe D (2008) Agriculture. In: The effects of climate change on agriculture, land resources, water resources, and biodiversity in the United States. https://www.usda.gov/oce/climate_change/SAP4_3/CCSPFinalR eport.pdf. Accessed 3 Nov 2018

Hatfield JL, Boote KJ, Kimball BA, Ziska LH, Izaurralde RC, Ort D, Thomson AM, Wolfe DW (2011) Climate impacts on agriculture: implications for crop production. Agron J 103:351-370. https:// doi.org/10.2134/agronj2010.0303

Hijmans RJ, Cameron SE, Parra JL, Jones PG, Jarvis A (2005) Very high resolution interpolated climate surfaces for global land areas. Int J Climatol 25:1965-1978. https://doi.org/10.1002/joc.1276

Iiyama M, Derero A, Kelemu K, Muthuri C, Kinuthia R, Ayenkulu E, Kiptot E, Hadgu K, Mowo J, Sinclair F (2016) Understanding patterns of tree adoption on farms in semiarid and sub-humid Ethiopia. Agrofor Syst. https://doi.org/10.1007/s10457-016-9926-y

Jenkerson CB, Maiersperger T, Schmidt G (2010) eMODIS: a userfriendly data source: US Geological Survey Open-File Report 2010-1055

Kaur S, Kaur H (2017) Climate change begs for policy initiatives in South Asia. https://www.eastasiaforum.org/2017/08/26/climatechange-begs-for-policy-initiatives-in-south-asia/. Accessed 10 Oct 2018

Kumar BM (1999) Agroforestry in the Indian tropics. Indian J Agrofor 1(1):47-62

Kumar BM, Takeuchi K (2015) Agroforestry in the Western Ghats of peninsular India and the satoyama landscapes of Japan: a comparison of two sustainable land use systems. Sustain Sci 4(2):215232. https://doi.org/10.1007/s11625-009-0086-0

Kuyah S, Oborn I, Jonsson M, Dahlin AS, Barrios E, Muthuri C, Malmer A, Nyaga J, Magaju C, Namirembe S, Nyberg S, Sinclair FL (2016) Trees in agricultural landscapes enhance provision of ecosystem services in Sub-Saharan Africa. Int J Biodivers Sci Ecosyst Serv Manag. https://doi.org/10.1080/21513 732.2016.1214178

Lal M, Cubasch U, Voss R, Waszkewitz J (1995) Effect of transient increases in greenhouse gases and sulphate aerosols on monsoon climate. Curr Sci 69(9):752-763

Leuschner WA, Khaleque K (1987) Homestead agroforestry in Bangladesh. Agrofor Syst 5:139. https://doi.org/10.1007/BF00047518

Lewis P, Monem MA, Impiglia A (2018) Impacts of climate change on farming systems and livelihoods in the near east and North Africa-with a special focus on small-scale family farming. FAO, Cairo, p 92

Li Z, Huffman T, Mcconkey B, Townley-Smith L (2013) Monitoring and modeling spatial and temporal patterns of grassland dynamics using time-series MODIS NDVI with climate and stocking data. Remote Sens Environ 138:232-244. https://doi. org/10.1016/j.rse.2013.07.020

Lipper L, Thornton P, Campbell BM et al (2014) Climate-smart agriculture for food security. Nat Clim Change 4:1068-1072. https://doi.org/10.1038/nclimate2437

Lopresti MF, Di Bella CM, Degioanni AJ (2015) (2015) Relationship between MODIS-NDVI data and wheat yield: a case study in Northern Buenos Aires province. Argent Inf Process Agric 2:73-84. https://doi.org/10.1016/j.inpa.2015.06.001

Mbow C, Smith P, Skole D, Duguma L, Bustamante M (2014) Achieving mitigation and adaptation to climate change through sustainable agroforestry practices in Africa. Curr Opin Environ Sustain 6:8-14. https://doi.org/10.1016/j.cosust.2013.09.002

Mendelsohn R (2014) The impact of climate change on agriculture in Asia. J Integr Agric 13(4):660-665. https://doi.org/10.1016/ S2095-3119(13)60701-7 
Meneses-Tovar CL (2011) NDVI as indicator of degradation. https ://www.fao.org/docrep/015/i2560e/i2560e07.pdf. Accessed 3 Oct 2018

Montagnini F, Metzel R (2017) The contribution of agroforestry to sustainable development goal 2: end hunger, achieve food security and improved nutrition, and promote sustainable. Agriculture. https://doi.org/10.1007/978-3-319-69371-2_2

Moulatlet GM, Zuquim G, Figueiredo FOG et al (2017) Using digital soil maps to infer edaphic affinities of plant species in Amazonia: problems and prospects. Ecol Evol 7:8463-8477. https:// doi.org/10.1002/ece3.3242

Nachtergaele F, Velthuizen HV, Verelst L (2009) Harmonized world soil database. (version 1.1).FAO, Rome, Italy and IIASA, Laxenburg, Austria

Nair PKR (1984) Soil productivity aspect of agroforestry. Nairobi, ICRAF, $\mathrm{p} 85$

Nair PKR (2011) Agroforestry systems and environmental quality: introduction. J Environ Qual 40(3):784-790. https://doi. org/10.2134/jeq2011.0076

Nair PKR, Garrity D (2012) Agroforestry - the future of global land use-2012. 10.1007/978-94-007-4676-3

NAP (2014) National Agroforestry Policy of India. https://www.india environmentportal.org.in/files/file/Agroforestry\%20policy $\% 20$ 2014.pdf. Accessed 10 Dec 2018

NCAR GIS Program (2012) Climate Change Scenarios, version 2.0. Community Climate System Model, June 2004 version 3.0. https://www.cesm.ucar.edu/models/ccsm3.0/ was used to derive data products. NCAR/UCAR. https://gisclimatechang e.ucar.edu/. Accessed 5 Mar 2018

Ospina C (2017) Climate and economic benefits of agroforestry systems. The Climate Institute, Washington. https://climate.org/ wp-content/uploads/2017/03/Agroforestry-Article-3.6.17.pdf. Accessed 5 Mar 2019

Ramanathan V, Chung C, Kim D, Bettge T, Buja L, Kiehl JT, Washington WM, Fu Q, Sikka DR, Wild M (2005) Atmospheric brown clouds: impacts on South Asian climate and hydrological cycle. Proc Natl Acad Sci USA 102:5326-5333. https://doi. org/10.1073/pnas.0500656102

Ranashinghe DMSHK, Newman SM (1993) Agroforestry research and practice in Sri Lanka. Agrofor Syst 22(2):119-130. https:// doi.org/10.1007/BF00705141

Reisner Y, de Filippi R, Herzog F et al (2007) Target regions for silvoarable agroforestry in Europe. Ecol Eng 29:401-418. https ://doi.org/10.1016/j.ecoleng.2006.09.020

Ritung S, Wahyunto AF, Hidayat H (2007) Land suitability evaluation with a case map of Aceh Barat District. Indonesian Soil Research Institute and World Agroforestry Centre, Bogor (ISBN: 979-3198-36-1)

Shrestha MS (2008) Impacts of floods in South Asia. J South Asia Disaster Stud 1(1):85-106. https://www.researchgate.net/publi cation/259484329_Impacts_of_flood_in_South_Asia

Tateishi R, Uriyangqai B, Al-Bilbisi H, Ghar MA, Tsend-Ayush J, Kobayashi T et al (2011) Production of global land cover data-GLCNMO. Int J Digit Earth 4(1):22-49. https://doi. org/10.1080/17538941003777521

Thapa G (2004) Rural poverty reduction strategy for South Asia. IFAD. Rome. https://devpolicy.crawford.anu.edu.au/acde/asarc/ pdf/papers/2004/WP2004_06.pdf. Accessed 3 Nov 2018

Thenkabail P, Teluguntla P, Xiong J, Oliphant A, Massey R (2016) NASA MEaSUREs Global Food Security Support Analysis
Data (GFSAD) Crop Mask 2010 Global $1 \mathrm{~km}$ V001. NASA EOSDIS Land Processes DAAC. https://doi.org/10.5067/ MEaSUREs/GFSAD/GFSAD1KCM.001

Thorlakson T, Neufeldt H (2012) Reducing subsistence farmers' vulnerability to climate change: evaluating the potential contributions of agroforestry in western Kenya. Agric Food Secur 1(15):1-13. https://doi.org/10.1186/2048-7010-1-15

Torquebiau E (ed) (2016) Climate change and agriculture worldwide. Springer, Dordrecht (Netherlands), 348 p. https://doi. org/10.1007/978-94-017-7462-8

Trabucco A, Zomer RJ (2009) Global aridity index (global-aridity) and global potential evapo-transpiration (Global-PET) geospatial database. CGIAR consortium for spatial information. Published online, available from the CGIAR-CSI GeoPortal at: http://www.csi.cgiar.org. Accessed 10 Nov 2018

Trabucco A, Zomer RJ, Bossio DA, van Straaten O, Verchot LV (2008) Climate change mitigation through afforestation/reforestation: a global analysis of hydrologic impacts with four case studies. Agric Ecosyst Environ 126:81-97. https://doi. org/10.1016/j.agee.2008.01.015

Trenberth KE, Hoar TJ (1997) El Nino and climate change. Geophys Res Lett 24:3057-3060. https://doi.org/10.1029/97GL03092

UNEP (United Nations Environment Programme) (1997) World atlas of desertification 2ED. UNEP, London (0-340-69166-2)

United Nations (2009) World Population Prospects: the 2008 revision population database. https://www.un.org/esa/population/ publications/wpp2008/wpp2008_highlights.pdf. Accessed 10 June 2018

van Noordwijk M, Duguma LA, Dewi S, Leimona B, Catacutan D, Lusiana B, Öborn I, Hairiah K, Minang PA (2018) SDG synergy between agriculture and forestry in the food, energy, water and income nexus: reinventing agroforestry? Curr Opin Environ Sustain 34:33-42

Waldron A, Miller DC, Redding D, Mooers A et al (2017) Reductions in global biodiversity loss predicted from conservation spending. Nature 551:364-367. https://doi.org/10.1038/natur e24295

Zhai P, Pan X (2003) Trends in temperature extremes during 1951-1999 in China. Geophys Res Lett 30:1913. https://doi. org/10.1029/2003GL018004

Zhao C, Liu B, Piao S et al (2017) Temperature increase reduces global yields of major crops in four independent estimates. Proc Natl Acad Sci 114(35):9326-9331. https://doi.org/10.1073/ pnas. 1701762114

Zomer RJ, Bossio DA, Trabucco A, Yuanjie L, Gupta DC, Singh VP (2007) Trees and water: smallholder agroforestry on irrigated lands in Northern India. International Water Management Institute, Colombo. https://doi.org/10.3910/2009.122

Zomer RJ, Trabucco A, Coe R, Place F (2009) Trees on farms: analysis of the global extent and geographical patterns of agroforestry. ICRAF Working Paper No. 89. World agroforestry centre: Nairobi, Kenya. http://www.worldagroforestry.org/downloads/ Publications/PDFS/WP16263.pdf . Accessed 6 Dec 2018

Zomer RJ, Neufeldt H, Xu J, Ahrends A, Bossio D, Trabucco A, van Noordwijk M, Wang M (2016) Global tree cover and biomass carbon on agricultural land: the contribution of agroforestry to global and national carbon budgets. Sci Rep 6:29987. https://doi. org/10.1038/srep29987 


\section{Affiliations}

\section{Firoz Ahmad ${ }^{1}$ (D) Md. Meraj Uddin ${ }^{2} \cdot$ Laxmi Goparaju$^{1} \cdot$ Javed Rizvi ${ }^{3} \cdot$ Chandrashekhar Biradar $^{4}$}

Md. Meraj Uddin

merajuddin.uddin@gmail.com

Laxmi Goparaju

goparajulaxmi@yahoo.com

Javed Rizvi

J.Rizvi@cgiar.org

Chandrashekhar Biradar

C.Biradar@cgiar.org

1 Vindhya Bachao Secretariat, Vindhyan Ecology and Natural History Foundation, 36/30, Shivpuri Colony, Station Road, Mirzapur, Uttar Pradesh 231001, India
2 University Department of Mathematics, Ranchi University, Ranchi, Jharkhand, India

3 World Agroforestry (ICRAF), South Asia Regional Program, New Delhi, India

4 International Center for Agricultural Research in the Dry Areas (ICARDA), Cairo, Egypt 